\title{
HERITAGE KOTA PONTIANAK SEBAGAI SUMBER BELAJAR DALAM PEMBELAJARAN SEJARAH
}

\author{
Haris Firmansyah \\ Program Studi Pendidikan Sejarah FKIP Universitas Tanjungpura \\ Email: harisfirmansyah@untan.ac.id
}

\begin{abstract}
Abstrak
Tujuan dilaksanakannya penelitian ini yakni: (1) Mengetahui apa sajakah Heritage yang terdapat di Kota Pontianak, bagaimana guru memanfaatkan Heritage kota Pontianak sebagai sumber belajar dalam pembelajaran sejarah, apa sajakah faktor pendukung dan penghambat dalam memanfaatkan Heritage kota Pontianak sebagai sumber belajar dalam pembelajaran sejarah. Penelitian ini dilakukan pada SMA sekota Pontianak. Metode penelitian yang digunakan dalam penelitian ini adalah studi deskriptif dengan pendekatan yang digunakan yakni kualitatif. Hasil penelitian adalah 1) Heritage Kota Pontianak dapat kita klasikasikasikan menjadi tiga bagian yakni: Islam, Hindia-Belanda dan Cina Identifikasi 2) Dalam pelaksanaan pembelajaran sejarah beberapa SMA di Kota Pontianak telah memanfaatkan heritage sebagai sumber belajar dalam pembelajaran sejarahnya. Namun pemanfaatan heritage tersebut belum digunakan secara maksimal. Dan 3) Factor pendukung utama adalah dukungan dari sekolah Yang kedua adalah sambutan baik dari lokasi heritage yang dikunjungi. Dan faktor penghambat dalam pelaksanaan adalah transportasi, Pendanaan, dan materi yang didapat terbatas.
\end{abstract}

Kata Kunci: heritage; Pontianak; guru dan siswa;

\begin{abstract}
The objectives of this research are: (1) Knowing what Heritage is in Pontianak City, how teachers use Pontianak City Heritage as a source of learning in history learning, what are the supporting and inhibiting factors in utilizing Pontianak City Heritage as a source of learning in history learning. This research was conducted at high schools throughout Pontianak. The research method used in this research is a descriptive study with the approach used that is qualitative. The results of the study are 1) Pontianak City Heritage can we classify it into three parts namely: Islam, Dutch East Indies and Chinese Identification 2) In the implementation of historical learning several high schools in Pontianak have used heritage as a source of learning in learning history. But the use of heritage has not been used to its full potential. And 3) The main supporting factor is support from the school. The second is good reception from the heritage sites visited. And the inhibiting factors in the implementation are transportation, funding, and the material obtained is limited.
\end{abstract}

Keywords: heritage; Pontianak; teachers and students;

\section{PENDAHULUAN}

Heritage memiliki beberapa bagian yakni heritage alam, budaya dan saujana. Dalam penelitian ini yang menjadi pembahasan/fokus adalah heritage budaya. Heritage adalah hasil cipta, rasa, karsa dan karya yang istimewa. Dengan kata lain segala sesuatu (baca: benda/bangunan) yang termasuk heritage budaya merupakan hasil dari produk masa lalu (sejarah). 
Heritage merupakan warisan budaya yang memiliki corak khas atas tradisi. Sebagaimana definisi yang diberikan Unesco tentang 'Heritage' adalah warisan (budaya) masa lalu, apa yang saat ini dijalani manusia, dan apa yang diteruskan kepada generasi mendatang. Sebagai bentuk warisan dari pendahulu tentu heritage menjadi penting untuk dijaga dan dilestari dari generasi ke generasi.

Heritage dapat juga disebut dengan Istilah Benda Cagar Budaya (BCB) yang mulai dipakai sejak tahun 1992, yaitu dengan adanya Undang-Undang RI No. 5 Tahun 1992 tentang Benda Cagar Budaya. Menurut Undang-Undang No. 5 Tahun 1992 yang dimaksud Benda Cagar Budaya

Kota Pontianak salah satu kota yang memiliki banyak penginggalan bersejarah (heritage), selain Istana Qadariah yang menjadi ikon sejarah kota pontianak ada juga peninggalan bangunan-bangunan bersejarah bernuansa indis yang merupakan peninggalan dari pemerintahan Hindia Belanda. Letak kota kolianal Hindia Belanda di kota Pontianak berada di daerah Taman Alun Kapuas, dengan letak di Taman Kota dan di pinggiran sungai Kapuas membuat daerah ini sering dikunjungi oleh banyak masyarakat. Namun sangat disayangkan masih banyak sekali masyarakat tidak mengetahui bahwa Taman Alun Kapuas yang sering dikunjunginya itu memiliki sejarahnya sendiri.

Cagar Budaya yang ada di Kota Pontianak tentu belum banyak yang diketahui oleh masyarakat, oleh sebab itu maka mengenalkan dan mengajak untuk ikut serta dalam melakukan pelestarian cagar budaya yang terdapat di Kota Pontianak menjadi penting dilakukan, terutama kepada anak muda. Anak muda yang masih termasuk dalam usia sekolah penting untuk mengenal cagar budaya yang terdapat di kotanya. Mereka sebagai generasi penerus harus mengenal identitas daerahnya sendiri.

Mengenalkan heritage atau cagar budaya yang terdapat di daerah kepada siswa dapat dimasukan dalam pembelajaran sejarah di sekolah. terutama saat ini dalam implementasi kurikulum 2013, pembelajaran sejarah mengharuskan siswa memahami sejarah lokal daerahnya dan memhami nilai-nilai kearifan lokalnya.

Pembelajaran sejarah lokal untuk siswa bukan berarti hanya belajar tentang masa lalu yang tiada guna, namun akan memberikan manfaat untu masa 
kini dan yang akan datang karena sejarah merupakan dialog antara peristiwa masa lampau dan perkembangan di masa depan (Kochhar, 2008). Peninggalan tersebut salah satu bentuknya adalah bangunan bersejarah, dari bangunan bersejarah kita bisa mempelajari bagaimana kota tersebut terbentuk di masa lalu.

Pembelajaran sejarah tidak hanya transfer of knowledge kejadian masa silam saja, yang sering kali membuat siswa merasa bosan di dalam ruangan dan bertanya-tanya apa manfaat belajar dari masa lalu, tetapi pembelajaran sejarah merupakan upaya membentuk karaktek peserta didik agar lebih mengenal diri dan lingkungannya. Tanpa pengenalan itu, seseorang dapat kehilangan orientasi hidup, juga cara berpikir dan prilaku sehari-hari (Hamid, 2014).

Pembelajaran sejarah sering dianggap sebagai pembelajaran yang membosankan, sehingga siswa banyak yang tidak tertarik dengan pembelajaran ini. Kebanyakan kasus di sekolah, kita sering menjumpai siswa merasa mengantuk bahkan ada yang sudah sampai tertidur ketika pembelajaran sedang berlangsung. Hal ini tentu akan membuat tujuan pembelajaran tidak akan tercapai. Kasus seperti ini membuat guru sejarah harus mampu memilih dan melakasanakan startegi dan metode pembalajran yang cocok untuk kelas agar tujuan pembelajaran tercapai secara efektif dan optimal.

Menurut Isjoni (2007), pembelajaran sejarah agar menarik dan menyenangkan dapat dilaksanakan dengan berbagai cara, misalnya seperti mengajak siswa pada peristiwa-peristiwa sejarah yang terjadi di sekitar mereka. Lingkungan sekitar terdapat berbagai peristiwa sejarah yang dapat membantu guru mengembangkan pemahaman siswa tentang masa lalu. Umumnya siswa akan lebih tertarik terhadap sejarah bila berhubungan dengan situasi nyata disekitar.

Pada proses pembelajaran sejarah ini guru dapat memanfaatkan heritage yang ada di kota pontianak sebagai salah satu sumber belajar sejarah guna menggenalkan sejarah lokal kepada siswa dan memberikan pemahanan tentang nilai-nilai kearifan lokal yang dapat diambil dari heritage tersebut. Berangkat dari semua pemaparan diatas, maka penulis tertarik untuk mengangkat penelitian dengan judul "Heritage kota Pontianak sebagai sumber belajar dalam pembelajaran sejarah SMA se-Kota Pontianak". 


\section{METODE}

Penelitian ini merupakan penelitian dasar dengan menggunakan metode penelitian studi deskriptif. Dalam kegiatan studi deskriptif ini akan digali berbagai data yang berhubungan dengan Heritage kota Pontianak sebagai sumber belajar dalam pembelajaran sejarah SMA se-Kota Pontianak.

Adapun sumber data yang digunakan dalam penelitian ini adalah : 1) Informan yaitu seseorang atau sesuatu yang dapat memberikan informasi tentang penelitian ini. Pada penelitian ini informan awal terdiri dari guru sejarah SMA seKota Pontianak yang pernah memanfaatkan heritage sebagai sumber belajar dalam pembelajaran sejarah. 2) Tempat dan peristiwa yaitu kegiatan yang berhubungan dengan Heritage kota Pontianak sebagai sumber belajar dalam pembelajaran sejarah SMA se-Kota Pontianak. Dan 3) Dokumen berupa dokumen surat-surat, arsip, foto maupun rekaman didapat dari sumber baik Informan Maupun yang berasal dari tempat Penelitian serta dokumentasi yang dimiliki oleh person maupun lembaga tertentu.

Teknik pengumpulan data yang digunakan dalam penelitian ini adalah sebagai berikut: 1) Wawancara mendalam (indepth interview) yang dilakukan lebih menyerupai suatu bentuk dialog antara peneliti dan informan dilakukan dalam suasana santai. Agar wawancara mendalam lebih terarah maka dipersiapkan pedoman wawancara (interview guide) yang berisi tentang pertanyaan-pertanyaan sesuai dengan rumusan dan tujuan penelitian ini. Dan 2) Mengkaji dokumen dan arsip (content analysis) tentang Heritage kota Pontianak sebagai sumber belajar dalam pembelajaran sejarah SMA se-Kota Pontianak, sumber data ini merupakan data penting untuk menemukan data yang beragam sesuai dengan kebutuhan dan tujuan penelitian.

Validitas data yang dikembangkan dalam penelitian adalah teknik trianggulasi sumber dan trianggulasi metode. Trianggulasi data (sumber) menjadi pilihan karena dapat memanfaatkan jenis sumber data yang berbeda, sedangkan trianggulasi metode dilakukan untuk lebih memantapkan hasil pengumpulan data yang kemudian hasilnya ditarik simpulan data yang lebih kuat validitasnya. Jadi 
antara trianggulasi data (sumber) dengan trianggulasi metode nanti diharapkan ada kesesuaian dalam perumusan analisis hasil interpretasi dan wawancara (Sutopo, 2006: 91-96).

Penelitian yang dilakukan bersifat deskriptif-kualitatif dengan tehnik analisis interaktif (Miles dan Huberman, 1984: 22-23). Adapun alasan penelitian kualitatif di atas dimaksudkan untuk lebih mementingkan proses pengumpulan data beragam dan disusun sebagai kekhususan untuk dikelompokkan bersama melalui proses pengumpulan data secara teliti serta saling berkaitan (bottom up grounded theory) (Sutopo, 2006: 41). Analisis ini dilakukan bersamaan dengan proses pelaksanaan di lapangan yang disusun secara lentur dan terbuka (Sutopo, 2006: 42) sesuai dengan kondisi yang sebenarnya dan lebih menekankan pada pendekatan kritik dalam menelaah tentang Heritage kota Pontianak sebagai sumber belajar dalam pembelajaran sejarah SMA se-Kota Pontianak.

Teknik analisis interaktif ini memiliki tiga komponen analisis yaitu reduksi data, sajian data dan penarikan kesimpulan atau verifikasi yang digambarkan pada gambar di bawah ini :

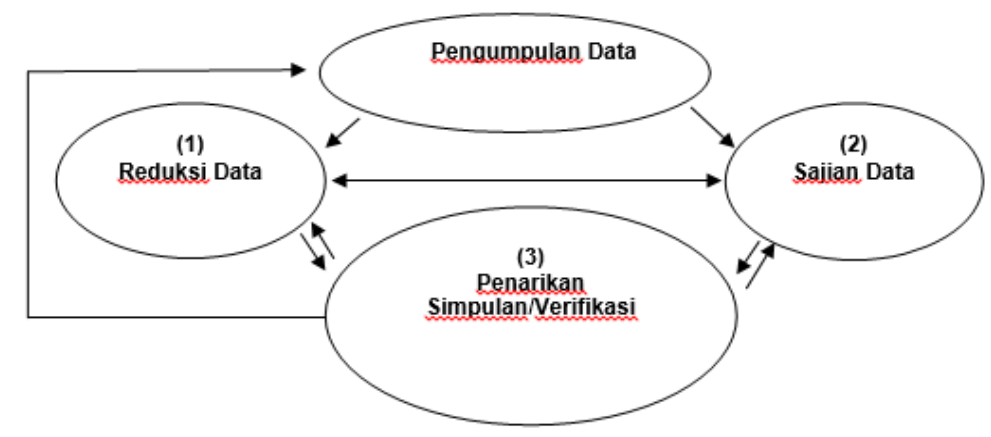

Bagan 1. Model Analisis Interaktif (Sutopo, 2006: 120)

Selanjutnya aktivitas penelitian hanya bergerak di antara tiga komponen analisis tersebut. Penyajian data sebagai alur penting dari kegiatan analisis interaktif digunakan untuk melihat hasil data observasi sebagai langkah awal penelitian. Sedangkan wawancara mendalam digunakan untuk menentukan proses analisis Heritage kota Pontianak sebagai sumber belajar dalam pembelajaran sejarah SMA se-Kota Pontianak secara sistematis dan objektif didukung proses analisis yang didapat dari sumber arsip dan dokumen yang didapat melalui metode 
kritik sumber intern dan ekstern. Kritik sumber tersebut digunakan untuk membantu interpretasi data yang diolah sehingga menghasilkan hipotesis yang obyektif. Setiap kelompok data yang telah direfleksi lalu saling dikomparasikan untuk menemukan perbedaan dan persamaan persepsi dalam tujuan penelitian awal sehingga simpulan yang didapat menjadi lebih jelas.

Analisis ketiga yang penting adalah menarik simpulan atau verifikasi. Peneliti memberi simpulan secara longgar, tetap terbuka dan skeptis. Model analisis ini memiliki kekuatan pada proses analisisnya yang dilakukan berulangulang, sehingga pada tahap ini diperoleh simpulan yang sesuai dengan tujuan penelitian. Pengumpulan data terakhir dilakukan dengan menarik simpulan /verifikasi berdasarkan reduksi dan sajian data. Kedalaman dan ketelitian proses analisis akan menentukan gambaran umum yang detil tentang Heritage kota Pontianak sebagai sumber belajar dalam pembelajaran sejarah SMA se-Kota Pontianak.

\section{HASIL DAN PEMBAHASAN}

\section{Identifikasi Heritage yang Terdapat di Kota Pontianak}

Untuk melakukan identifikasi heritage yang terdapat di kota Pontianak kita perlu melihat sekilas sejarah singkat kota Pontianak. Setiap tempat tentu ada jejak sejarahnya sendiri, peristiwa apa saja dan peninggalan apa saja yang ada pasti berbede-beda. Prof Eko Budiharjo pernah mengatakan "Kota tanpa kota lama, ibarat manusia tanpa ingatan”, apa yang disampaikan oleh Prof Eko Budhiarjo menggambarkan bahwa setiap kota pastilah ada peninggalan sejarahnya, peninggalan sejarah tersebut merupakan ingtan kolektif manusia yang saling berkaitan antara para pendahulu dan yang sekarang.

Salah satu kota yang juga memiliki peninggalan sejarah adalah Kota Pontianak. Sebagai tempat pertemuan sungai kapuas dan sungai landak menjadikan Pontianak menjadi tempat yang sangat strategis pada masanya. Sungai menjadikan pontianak sebagai pintu masuk ke pedalaman Kalimantan Barat. Tidak heran sudah sejak lama daerah ini telah menjadi rebutan. Pada tahun 23 oktober 1771 (14 Rajab 1185 H) Sultan Syarif Abdurahman mulai membuka 
daerah ini. Kemudian mendirikan Masjid dan Istana yang sekarang kita kenal sebagai Masjid Jami' Sultan Syarif Abdurahman dan Istana Kadriah. Dua bangunan tersebut sekarang menjadi Ikon Sejarah Kota Pontianak. Pasca pembukaan daerah masyarakt yang mengikuti Sultan Syarif Abdurahman mulai membuka perkampungan disekitran Istana dan mendirikan bangunan, salah satunya yang dapat kita lihat sekarang adalah Suaru Bait Annur yang didirikan pada $1216 \mathrm{H}$ atau bertepatan dengan tahun $1802 \mathrm{M}$ yang diidrikan oleh nahkoda Ahmad yang merupakan salah seoranh nahkoda kapal yang membawa rombongan Sultan Syarif Abdurahman sampai ke daerah delta sungai kapuas (Asma Dz, 2013: 19). Selain itu banyak lagi peninggalan sejarah yang becorak Islam lainnya.

Pada 5 Juli 1779 VOC mengadakan kontrak politik bersama Sultan Pontianak, perjanjian tersebut disebut 'Acte Van Investiture', kemudian VOC mendapatkan wilahyah selatanseberang Istana Kesultanan Pontianak yang kita kenal dengan nama Tanah Seribu (Duizen Vierkanten Paal) kerana meliputi areal tanah seluas 1000 x 1000 m, daerah ini sekarang dapat kita lihat sekitaran Taman Alun Kapus (Asma Dz, 2013:45). Di area tanah seribu inilah VOC dan Bangsa Belanda melakukan aktivitasnya dan mendirikan beberapa bangunan untuk pusat pemerintahan mereka. Beberapa bangunan peninggalan bangsa Belanda yang dapat kita lihat disekitaran taman alun kapuas sekarang seperti Bank Indonesia, Kantor Post, Gedung Bapeda, Gedung Kwarda Pramuka, SDN 14 Pontianak dan lainnya.

Selain bangsa belanda yang juga masuk ke kota pontianak ada juga Imigran cina yang mulai membuat komunitasnya sendiri. Imigran cina ini sebenar telah lama ada di Kalimantan Barat sebagai penambang emas yang tersebar dibeebrapa tempat dan kemudian meraka membuat kongsi dagangnya sendiri. Di wilayah Pontianak para Imigran Cina mendirikan perkampungan Khas Cina dan sekaligus menciptakan dalam satuan sosio-ekonomi sebagai satu komunitas yang produktif (Hasanuddin, 2014:34). Dibeberapa tempat komunitas cina ini sekarang kita dapat melihat beberapa heritage misalnya Vihara Bodhisatva Karaniya Meta, pelabuan Tan senghie dan lainnya. 
Berdasarkan penjelasan di atas Heritage Kota Pontianak dapat kita identifikasi menjadi tiga bagian yakni: Islam, Hindia-Belanda dan Cina. Heritage kota Pontianak baik yang sudah masuk cagar budaya menurut Dinas Kebudayaan dan Pariwisata Provinsi Kalimantan Barat pada tahun 2010 dan yang belum dapat kita lihat pada bagan dibawah ini:

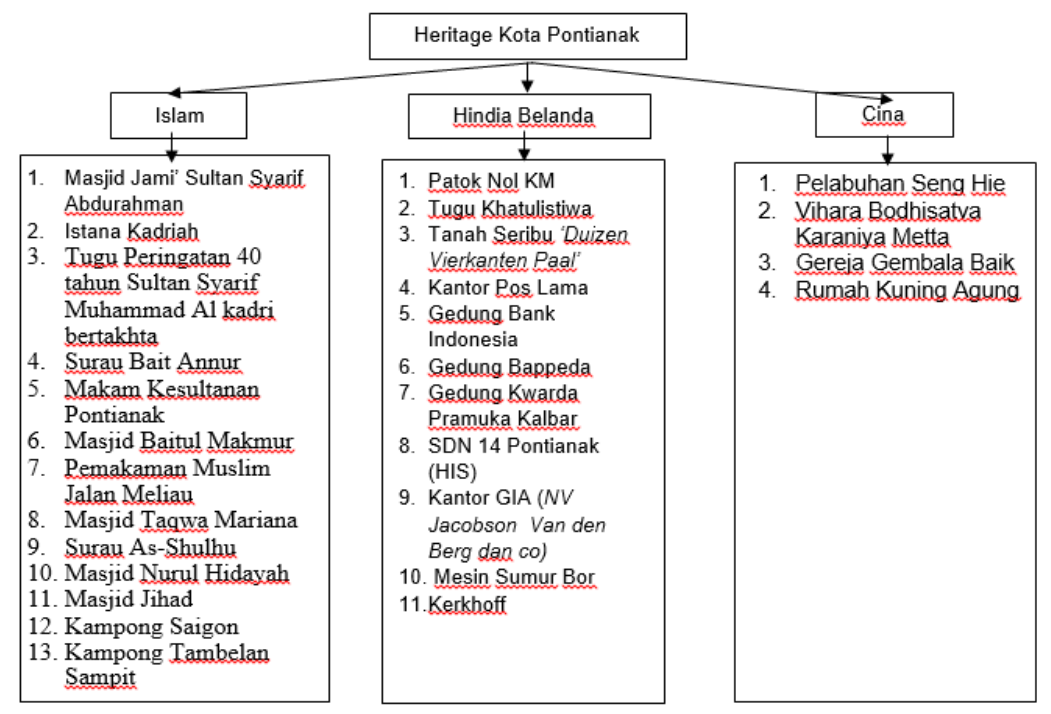

\section{Bagan 2. Identifikasi Heritage Kota Pontianak}

Identifikasi Heritage Kota Pontianak diatas dapat dimanfaatkan guru sebagai sumber belajar sejarah dan bisa disesauikan dengan materi yang dibahas.

\section{Pemanfaatan Heritage Kota Pontianak Sebagai Sumber Belajar dalam Pembelajaran Sejarah SMA Se-Kota Pontianak}

Pembelajaran sejarah hakikatnya memliki peran yang sangat vital yakni peran mengaktulisasikan dua unsur pembelajaran dan pendidikan. Antara lain unsurnya adalah (1) Pembelajaran (instruction) dan pendidikan intelektual (intellectual training). Pada unsur ini pembelajaran sejarah tidak hanya memberikan gambaran masa lampau saja, tetapi memberikan latihan berpikir kritis, menarik kesimpulan, menarik makna dan nilai dari peristiwa sejarah yang dipelajari. (2) Pembelajaran dan pendidikan moral bangsa dan civil society yang demokratis dan bertanggung jawab pada masa depan bangsa. Unsur ini menuntut 
pembelajaran sejarah berorientasi pada pendidikan kemanusiaan yang memperhatikan nilai-nilai dan norma-norma sehingga hasil dari pembelajaran sejarah mampu menjadikan siswa memiliki kepribadian kuat (Isjoni, 2007).

Untuk mencapai tujuan pembelajaran sejarah guru dituntut untuk dapat mengaktifkan kesadaran sejarah siswa. Dengan memanfaatkan realitas lingkungan guru dapat membawa siswa belajar sejarah secara langsung, kerena keterikatan siswa sebagai bagian manusia sosial yang hidup dilingkungannya sendiri tentu sangat efektif untuk mengaktifkan kesadaran sejarahnya. Lokalitas dapat menarik perhatian siswa untuk aktif dalam pembelajaran. Dalam hal ini guru dapat memanfaatkan peninggalan sejarah/heritage yang ada disekitar kota Pontianak.

Heritage dapat dijadikan sumber dalam belajar sejarah. Sumber pembelajaran dapat membantu guru dalam menyapaikan materi pembelajaran, sehingga info yang didapat oleh siswa lebih banyak. Dalam pembelajaran sejarah, semakin banyak sumber pembelajaran yang dieksplorasi oleh guru semakin sangat baik. Guru memiliki banyak pilihan untuk memanfaatkan sumber pembelajaran sejarah yang dapat digunakan dalam menyampaikan materi sejarah.

Hasil penelitian ini menunjukan bahwa dalam pembelajaran sejarah beberapa SMA di Kota Pontianak telah memanfaatkan heritage sebagai sumber belajar dalam pembelajaran sejarahnya. Namun pemanfaatan heritage tersebut belum digunakan secara maksimal. Guru sejarah lebih sering terfokus pada heritage yang sudah menjadi ikon utama kota Pontianak saja misalnya masjid jami' Sultan syarif Abdurahman dan Istana Kadriah sebagai materi sejarah perkembangan Islam.

Pembelajaran dapat bagi dalam tiga aspek yakni perencanaan, pelaksanaan dan evaluasi. Penjelasan pemanfaatan heritage sebagai sumber belajar dalam pembelajaran sejarah akan djelaskan berdasarkan tigas aspek pembalajaran tersebut.

\section{Perencanaan}

Dilihat dari terminologinya, perencanaan pembelajaran terdiri atas dua kata yakni 'perencanaan' dan 'pembelajaran'. Perencanaan berasal dari kata 
rencana yaitu pengambilan keputusan tentang apa yang harus dilakukan untuk mencapai tujuan (Agung dan Sri, 2013). Proses suatu perencanaan harus dimulai dari penetapan tujuan yang akan dicapai melalui anlisis kebutuhan serta dokumen yang lengkap, kemudian langkah-langkah yang harus dilakukan untuk mencapai tujuan tersebut. Sedangkan pembelajaran dapat diartikan sebagai proses kerja sama antara guru dan siswa dalam memanfaatkan segala potensi dan sumber yang ada baik potensi yang bersumber dari dalam diri siswaitu sendiri seperti minat, bakat dan kemapuan dasar yang dimiliki termasuk gaya belajar maupun potensi yang ada diluar diri siswa seperti lingkungan, serana dan sumber belajar sebagai upaya untuk mencapai tujuan belajar tertentu (Sanjaya, 2011).

Perencanaan pembelajaran harus disusun dengan baik, sehingga membuat proses pembelajaran akan berjalan sistematis sesuai dengan yang diharapkan. Menurut Kochar (2008) "perencanaan pembelajaran yang matang sangatlah penting, baik bagi guru berpengalaman maupun guru pemula. Bahkan, rencana pembelajaran adalah dasar pembelajaran yang efektif'.

Dalam pemanfatan heritage sebagai sumber belajar sudah seharus dikembangkan dalam perencanaan pembelajaran sejarah, agar diharapakn pelaksanaannya berjalan dengan baik. Pada hasil wawancara dengan infroman dalam hal ini guru sejarah SMA se-Kota Pontianak telah melakukan pengembangan perencanaan pembelajaran untuk pemanfaatan heritage sebagai sumber belajar sejarah sesuai dengan materi yang dibahas.

Pengembangan perencanaan pemanfataan heritage kota Pontianak sebagai sumber belajar dalam pembelajaran sejarah oleh guru SMA se-Kota Pontianak anatara lain:

1) Dimasukan dalam Perencanaan Program Tahunan Sekolah

2) Dimasukan dalam Program Kerja Tahunan Guru

3) Dimasukan dalam pengembangan Rencana Pelaksanaan Pembelajaran (RPP) sesuai dengan tema materi yang dibahas. 


\section{Pelaksanaan}

Pelaksanaan pembelajaran merupakan implementasi dari perencanaan pembelajaran yang telah disusun oleh guru. Pelaksanaan pembelajaran yang sangat penting adalah metode pembelajaran yang digunakan oleh guru. Memilih strategi dan metode yang tepat adalah tugas guru untuk mengelola pembelajaran menjadi efektif dan menarik. Mudasir (2011:66) mengatakan bahwa Peran seorang guru pada pengelolaan kelas sangat penting khususnya dalam menciptakan suasana pembelajran yang menarik. Itu karena secara prinsip, guru memegang dua tugas sekaligus masalah pokok, yakni pengajaran dan pengelolaan kelas. Pengajaran terkait usaha membantu siswauntuk mencapai tujuan pembelajaran. Sedangkan pengelolaan berkaitan dengan usaha untuk menciptakan dan mempertahankan kondisi sehingga proses pembelajaraan da;pat berjalan secara efektif dan efisien demi tercapainya tujuan pembelajaran.

Pembelajaran sejarah sering dianggap sebagai pembelajaran yang membosankan, sehingga siswabanyak yang tidak tertarik dengan pembelajaran ini. kebanyakan kasus di sekolah, kita sering menjumpai siswamerasa mengantuk bahkan ada yang sudah sampai tertidur ketika pembelajaran sedang berlangsung. Hal ini tentu akan membuat tujuan pembelajaran tidak akan tercapai. Kasus seperti ini harus membuat guru sejarah harus mampu memilih dan melakasanakan startegi dan metode pembalajran yang cocok untuk kelas agar tujuan pembelajaran tercapai secara efektif dan optimal.

Menurut Isjoni (2007), pembelajaran sejarah agar menarik dan menyenangkan dapat dilaksanakan dengan berbagai cara, misalnya seperti mengajak siswapada peristiwa-peristiwa sejarah yang terjadi di sekitar mereka. Lingkungan sekitar terdapat berbagai peristiwa sejarah yang dapat membantu guru mengembangkan pemahaman siswa tentang masa lalu. Umumnya siswaakan lebih tertarik terhadap sejarah bila berhubungan dengan situasi nyata disekitar.

Dalam pemanfaatan heritage sebagai sumber belajar dalam pembelajaran sejarah guru menggunakan metode 'Out Door Study' yakni pendekatan pembelajaran diluar kelas. Dalam pelaksanaannya harus benar-benar menyenangkan sehingga siswa betah untuk belajar. Pelaksaan 'Out Door Study' 
ini dalam pembelajaran sejarah disetiap sekolah SMA se-Kota Pontianak diberi nama program sendiri anatara lain disebut : lawatan Sejarah, Tour Sejarah, Kunjungan Sejarah.

Dalam Pelaksanan Out Door Study yang telah dimasukan dalam program tahunan dan melibatkan bantuan guru lain untuk ikut membantu proses pelaksanan pembelajarannya, maka sebelum turun ke lapangan adanya pembentukan panitia terlebih dahulu, terutama menyiapkan transportasi dan mengawasi siswa. Sebelum turun lapangan siswa dibagi dalam beberapa kelompok untuk mempermudah pengawasan dan agar efektif dilapangan. Setiap kelompok diberikan tugas berupa karya tulis atau makalah dimana setiap kelompok sudah diberikan tema sesuai dengan bangun sejarah yang dikunjungi (heritage). Setiap kelompok dibantu satu guru yang terlibat sebagai panitia.

Dilapangan siswa terlihat lebih aktif dalam pembelajaran dan sangat antusias ketika mendengarkan materi, mereka aktif bertanya tentang heritage yang dikunjungi. Ketika dilapangan mereka fokus mendengarkan materi yang disampaikan dan megambil foto bangunan tersebut.

\section{Evaluasi}

Menurut Sudijono (2012) secara harfiah kata evaluasi berasal dari bahasa Inggris 'evalution'; dalam bahasa arab 'al-taqdir'; dalam bahasa Indonesia berarti 'penilaian'. Akar katanya adalah 'value'; dalam bahasa Arab 'al-Qimah'; dalam bahasa Indonesia 'nilai'. Dengan demikian secara harfiah evaluasi pendidikan (educational evaluation=al-Tagdir al-Tarbawiy) dapat diartikan sebagai penilaian dalam bidang pendidikan atau penilaian mengenai hal-hal yang berkaitan dengan kegiatan pendidikan termasuk di dalamnya adalah pembelajaran.

Secara teoritis evaluasi adalah suatu usaha sistematik dan sistematik untuk mengumpulkan, menyusun, dan mengolah data, fakta, dan informasi dengan tujuan menyimpulkan nilai, makna, kegunaan, prestasi dari suatu program, dan hasil kesimpulan tersebut dapat digunakan dalam rangka pengambilan keputusan, perencanaan, maupun perbaikan dari suatu program. Ada tiga konsep yang sering dipakai dalam melakukan evaluasi, yakni: tes, pengukuran dan penilaian 
(Aman,2011). Kemudian Sudijono (2012) menyebutkan evaluasi memiliki tiga macam fungsi pokok sebagai suatu tindakan atau proses yaitu : (1) mengukur kemajuan, (2) menunjang penyusunan rencana, dan (3) memperbaiki atau melakukan pemnyempurnaan kembali.

Setelah pelakasanan pembelajaran tentu perlu melakukan evalusi guna mengkur keberhasilan pembelajaran. Dalam pemfaatan heritage kota Pontianak sebagai sumber belajar dalam pembelajaran sejarah SMA se-Kota Pontianak guru melakukan beberapa evaluasi antara lain adalah: tes tulisan (tes esai dan tes objektif), dan tes lisan.

1) Tes esai adalah bentuk tes dengan cara siswa diminta untuk menjawab pertanyaan secara terbuka yaitu menjelaskan atau menguraikan melalui kalimat yang disusunnya sendiri. Tes esai ini dapat menilai proses mental siswa terutama dalam hal kemampuan menyusun jawaban secara sistematis, kesanggupan menggunakan bahasa dan lain sebagainya. Tes esai dilakukan setelah siswa melakukan kunjungan dilapangan.

2) Tes objektif adalah bentuk tes yang mengharapkan siswa memilih jawaban yang sudah ditentukan. Tes objektif ini akan mengajarkan siswauntuk memiliki keyakinan dalam memilih jawab yang paling tepat dan benar. Materi heritage kota pontianak dimasukan dalam soal ujian akhir semster.

3) Tes lisan adalah bentuk tes yang menggunakan bahasa secara lisan. Tes ini bagus untuk menilai kemampuan nalar siswa. Guru dapat melihat secara detail bagaimana pemahaman siswanya terhadap materi yang telah diajarkan, yang bukan hanya pemahaman tentang konsep, akan tetapi bagaimana aplikasinya serta hubungannya dengan konsep lain, bahkan guru juga dapat mengungkapkan informasi tentang pendapat dan pandangan mereka tentang suatu yang dievaluasi tersebut dalam hal ini terkait dengan materi sejarah. 
Faktor Pendukung dan Penghambat dalam Memanfaatkan Heritage Kota Pontianak Sebagai Sumber Belajar dalam Pembelajaran Sejarah SMA SeKota Pontianak

Ketercapaian pembelajaran dapat dilihat dari faktor yang mendukung dan menghambatnya. Begitu juga dalam konteks pemanfaatan heritage kota Pontianak sebagai sumber belajar dalam pembelajaran sejarah SMA se-Kota Pontianak.

Faktor pendukung utama adalah dukungan dari sekolah, hal itu sangat penting karena kalau tidak diizinkan untuk keluar maka tour sejarahnya tidak bisa dilaksanakan. Yang kedua adalah sambutan baik dari lokasi heritage yang dikunjungi, sehingga siswa dapat materi langsung disana.

Faktor penghambat dalam pelaksanaan adalah 1) transportasi, karena jumlah siswa yang menjadi peserta sangat banyak sehinggat sulit menyiapkan transportasinya. 2) Pendanaan, untuk terlaksananya kegiatan pembelajaran diluar kelas membutuhkan dana yang besar. Dan 3) materi yang didapat terbatas, kesulitan sumber setiap heritage juga menjadi penghambat dlam pemanfataannya sebagi sumber belajar.

\section{SIMPULAN}

Kesimpulan penelitian ini adalah 1) Heritage Kota Pontianak dapat kita klasikasikasikan menjadi tiga bagian yakni : Islam, Hindia-Belanda dan Cina Identifikasi Heritage Kota Pontianak tersebut dapat dimanfaatkan guru sebagai sumber belajar sejarah dan bisa disesauikan dengan materi yang dibahas. 2) Dalam pelaksanaan pembelajaran sejarah beberapa SMA di Kota Pontianak telah memanfaatkan heritage sebagai sumber belajar dalam pembelajaran sejarahnya. Namun pemanfaatan heritage tersebut belum digunakan secara maksimal. Guru sejarah lebih sering terfokus pada heritage yang sudah menjadi ikon utama kota Pontianak saja misalnya masjid jami' Sultan syarif Abdurahman dan Istana Kadriah sebagai materi sejarah perkembangan Islam. Pemanfaatan heritage sebagai sumber belajar dalam pembelajaran sejarah guru menggunakan metode 'Out Door Study' yakni pendekatan pembelajaran diluar kelas. Dalam pelaksanaannya harus benar-benar menyenangkan sehingga siswa betah untuk 
belajar. Pelaksaan 'Out Door Study' ini dalam pembelajaran sejarah disetiap sekolah SMA se-Kota Pontianak diberi nama program sendiri anatara lain disebut: lawatan Sejarah, Tour Sejarah, Kunjungan Sejarah. Evaluasi dalam pemafaatan heritage kota Pontianak sebagai sumber belajar dalam pembelajaran sejarah SMA se-Kota Pontianak guru melakukan beberapa evaluasi antara lain adalah : tes tulisan (tes esai dan tes objektif), dan tes lisan. 3) Factor pendukung utama adalah dukungan dari sekolah Yang kedua adalah sambutan baik dari lokasi heritage yang dikunjungi. Dan faktor penghambat dalam pelaksanaan adalah 1) transportasi, 2) Pendanaan, dan 3) materi yang didapat terbatas.

\section{DAFTAR PUSTAKA}

Sutopo. H.B. 2006. Metode Penelitian Kualitatif Dasar Teori dan Penerapanya Dalam Penelitian. Surakarta: UNS Press.

Asma dz, Ahmad. 2013. Pontianak Heritage dan Beberapa yang Berciri Khas. Pontrianak: Literer Khatulistiwa.

Agung, Leo dan Sri Wahyuni. 2013. Perencanaan Pembelajaran Sejarah. Yogyakarta : Penerbit Ombak.

Sanjaya, Wina. 2011. Perencanaan dan Desain Sistem Pembelajaran. Jakarta: Kencana Prenanda Media Group.

Mudasir. 2011. Manajemen Kelas. Yogyakarta: Nusa Media.

Aman. 2011. Model Evaluasi Pembalajaran Sejarah. Yogyakarta: Penerbit Ombak.

Hamid, Abd. Rahman. 2014. Pembelajaran Sejarah. Yogyakarta: Penerbit Ombak.

Hasanuddin. 2014. Pontianak Masa Kolonial. Yogyakarta: Penerbit Ombak

Isjoni. 2007. Pembelajaran Sejarah Pada Satuan Pendidikan. Bandung: Alfabeta.

Kochar. 2008. Pembelajaran Sejarah; Teaching of History. Jakarta: PT Grasindo. 